\title{
KEINGINAN MENGGUNAKAN METODE KONTRASEPSI PADA REMAJA DI MASA MENDATANG DI PROVINSI JAWA TIMUR
}

\author{
Turul Fajiriyah ${ }^{1}$, Nunik Puspitasari ${ }^{2}$ \\ 1: Fakultas Kcschatan Masyarakai. Universtas Airlangga \\ Alamat kurespondensi: Nurzil Fajriyah \\ Thail: nurul tajriyahgresik 0 gmail com
}

\begin{abstract}
Achievemen of Population, Family Planning and Family Development progran during the last five years (2007. 21) 12 has stagnated with TFR 2.6. The government change the main focus of family plaming on adolescent groups since 2013. The pupose of this study was to andyze the relation of viriables with the atolescent s proference to use contracoption method of the future in East tand porize at 2015. This research is an analvic quantitative research with eross-sectional design that eonsisted of RP JMN year 2015 as secondary ata. The sample size are 2,384 adotosents that wmariod and 15-24 years old perind Juntary of Decenthe 2015 in Eust kwa frovince: Irdeperident variables were age, sex, place and edication level. The results of this study indicate 56,2 p want to use contraception method in the future. After calculated by researcher; it showed that age had $p=0$.000, gender had $p=0.000$, place had $p=0.003$, and education level had $p=0.000$. The conclusion of this stutly is that there are relationship between age, sex, place, and education level with the preference to use contraception method later used chi-square test. BKKBN cooperate with ambassadors of plamed generation, and educators should socialization of fumily flaning (KB) to motivate young people that plan their fanilies in the future. In addition, need to increase knowledge about repoductive healt hand family planing for adolesents:
\end{abstract}

Keywords: contraceptive method adoleseen, future

\section{ABSTRAK}

Pencapaian program Kependudukan, KB, dan Pembangunan Keluarga (KKBPK) sclama lima tahun terakhit (2007-2012) mengalami stagnan dengan THR 2.6. Hal ini memhual pemerintah mengalihkan lokus ulama penggarapan KB pada kelompok remaja sejak tahun 2013. Penelitian in untuk menganalisis variabel yang berhubungan dengan keinginan mengeunakan metode kontrasepsi di masa mendatang pada romają Provinsi Jawa Timur tahur 2015. Ienelitian ini menggunakan pendekatan kuantitatif dengan rancang bangun cross sechonal bersumber dari survei indikalor kinerja RPJMN Tahun 2015. Besar sampel penelitian ini berjumlah 2.384 remaja 15-24 tăhun yang belum menikah periode Januari hingga Desenber 2015 di Provinsi Jawa Timur, Variabel bebas yang diteliti yakni usia, jenis kelamin, dan lingkat pendidikann. Nilâi p masing-nasing variabel yakní usia $(\mathrm{p}=0,000)$, jenis kelamin $(\mathrm{p}=0,000)$, tempat tinggal $(\mathrm{p}=0,003)$, dan tingkat pendidikan $(\mathrm{p}=0,000)$. Kesimpulan penelitian in adalah ada hubungan antara usia, jeris kelamin, tempat tinggal, dan tingkat pendidikan berdasarkan hasil uji chi-square. Disarankan untuk BKKBN berkerjasama dengan duta Cenerasi Berencana, dan tenaga pendidik untuk lebih meningkatkan sosialisi tentang Keluarga Berencana (KB) agar dapat memberikan motivasi kepala kaum muda dalam merencanakan keluargat dimasa mendatang. Selain itu perlunya peningkatan pengetahuan kesehatan reproduksi dan KB bagi remaja.

Kata kunci: keluarga berencana, remaja masa mendalang

\section{PENDAHULUAN}

Permasalahan yang dialami oleh negara berkembang termasuk Indonesia adalah Permasalahan yang dialami oleh negara berkembang termasuk Indonesia adalah laju pertumbuhan penduduk. Jawa Timur mengalami peningkatan LPP sebesar 0,06 menjadi 0,76 pada periode tahun $2000-2010$ dari 0,70 pada periode tahum 1990-2000 (BPS, 2015).

Upaya untuk menekan besarnya angka laju pertumbuhan penduduk oleh pemerintah pusat maupun pemerintah daerah masih belum maksimal. Pemerintah telah menetapkan kebijakan penyelenggaraan 
program Kependudukan Keluarga Berencana dan Pembangunan Keluarga (KKBPK) untuk mewujudkan penduduk tumbuh seimbang. Keberhasilan program KKBPK dapat dilihat dari aspek pengendalian kuantitas penduduk dan aspek peningkatan kualitas penduduk yang dapat diukur dengan peningkatan ketahanan dan kesejahteraan keluarganya.

Badan Kependudukan dan Keluarga Berencana Nasional (BKKBN) bertanggung jawab terhadap keberhasilan program KKBPK secara nasional. BKKBN menyusun Renstra 2015-2019 sebagai panduan bagi Pemerintah Kabupaten/Kota agar tidak salah arah atau kurang mendukung kebijakan nasional dalam pengendalian penduduk dan pembangunan keluarga. Kinerja BKKBN dalam program KKBPK dapat diukur dari hasil Survei Indikator Kinerja RPJMN. Survei RPJMN merupakan survei untuk memberikan gambaran pencapaian program dan dirancang menghasilkan estimasi parameter tingkat provinsi dan nasional (RPJMN, 2015).

Dilihat dari segi aspek pengendalian kuantitas penduduk, pencapaian program KKBPK selama 5 tahun terakhir (2007-2012) mengalami stagnan. Hal ini membuat pemerintah mengalihkan fokus utama penggarapan KB pada kelompok remaja sejak tahun 2013. Kematangan organ fisik (seksual) yang menyebabkan mampu bereproduksi dengan menghasilkan sperma oleh laki-laki dan sel telur oleh perempuan merupakan awal permulaan periode ini (Yusuf, 2009).

Menurut BKKBN, batasan usia remaja adalah 10-24 tahun. Berdasarkan proyeksî penduduk pada tahun 2015 menunjukkan bahwa jumlah remaja pada Provinsỉ Jawa Timur mencapai 9,12 juta atau sekitar $23,5 \%$ dari jumlah penduduk Jawa Timur 38,85 juta. Artinya terdapat 1 remaja dari setiap 4 orang penduduk Indonesia. (BPS, 2013).

Dilihat dari segi teoritis, besarnya proporsi penduduk berusia muda memiliki dua sisi. Pada satu sisi, penduduk usia muda yang. besar merupakan titik sentral pembangunan yang menjadi indikator suatu bangsa, apabila dapat dimanfaatkan secara tepat dan baik. Memanfaatkan mereka secara tepat dan baik diperlukan beberapa persyaratan. Di antaranya adalah kemampuan keahlian, kemampuan keterampilan dan kesempatan untuk berkarya.
Namun, apabila persyaratan tersebut tidak dapat dimiliki oleh penduduk usia muda, yang terjadi adalah sebaliknya, yaitu penduduk usia muda justru menjadi beban pembangunan (Laksmiwati, 2013).

Masalah menonjol dikalangan remaja diantaranya mengenai Kesehatan Reproduksi Remaja yakni seksualitas, Human Immunodeficiency Virus (HIV)/AIDS, Narkotika, Psikotropika dan Zat Adiktif (NAPZA), serta rendahnya pengetahuan remaja tentang Kesehatan Reproduksi Remaja (BKKBN, 2012). Remaja wanita lebih terpapar risiko keseliatan reproduksinya bila dibandingkan dengan remaja pria sepertî terjadinya kehamilan dan persalinan yang tidak diinginkan serta infeksi menular seksual (Mfone, 1998).

Progam KB bagi remaja bukan berarti menyediakan alat/cara kontrasepsi bagi remaja, melainkan program KB dimaksudkan melalui sosialisasi $\mathrm{KB}$ dan perencanaan kehamilan untuk membentuk keluarga yang berkualitas. Pentingnya sosialisasi program KB bagi remaja karena diperkirakan dalam 5 tahun depan mereka sudah akan memasuki kehidupan rumah tanigga yang sudah tentu akan memberikan kontribusi pada angka fertilitas. BKKBN telah mengampanyekan program KB bagi remaja melalui "GenRe (Generasi Berencana)" yaitu program yang dikembangkan untuk mempersiapkan dan merencanakan kehidupan berkeluarga bagi remaja ( $B K K B N, 2012$ ).

Salah satu upaya untuk mencegah permasalahan remaja sebagai akibat ledakan penduduk adalah dengan melakukan kontrol atau pengawasan terhadap pertumbuhan penduduk. Pertumbuhan penduduk dapat dikontrol diantaranya dengan menunda usia perkawinan dan penggunaan kontrasepsi untuk pembatasan jumlah anak. Kedua langkah tersebut diharapkan mampu mengendalikan kelahiran yang merupakan masalah pokok kependudukan. (Pașrah et. al, 2014).

Pemberian pendidikan tentang kesehatan reproduksi pada saat di sekolah sangat memberikan manfaat, seperti dalam beberapa penelitian sebelumnya menyimpulkan bahwa pendidikan seksualitas yang diberikan pada saat di sekolah tidak meningkatkan terjadinya hubungan seks dini pada remaja (UNFPA, 2000). 
Berdasarkan hasil SDKI 2012, hampir semua responden remaja sudah pernah mendengar sedikitnya satu alat kontrasepsi. Terdapat $90 \%$ remaja wanita yang mengetahui metode kontrasepsi modern. Metode pil, suntikan, dan kondom merupakan metode kontrasepsi modern yang paling banyak diketahui oleh remaja wanita. Metode kontrasepsi modern yanı bersifat jangka panjang kurang terkenal dikalangan remaja baik wanita maupun pria.

Remaja yang menyatakan ingin menggunakan metode kontrasepsi pada masa depan meningkat dalam lima tahun terakhir. Pada tahun 2007 , terdapat $37 \%$ remaja pria dan $72 \%$ remaja wanita yang menyatakan ingin menggunakan metode kontrasepsi di masa depan. Pada tahun 2012, terdapat 64\% remaja pria dan $77 \%$ remaja wanita yang menyatakan ingin menggunakan metode kontrasepsi di masa depan. (SDKI, 2012).

Namun kecenderungan angka fertilitas sulit diturunkan melihat masih tingginya ratarata jumlah anak yang diinginkan oleh remaja yang merupakan generasi penerus. Preferensi jumlah anak ideal pada remaja wanita dan remaja pria hampir sama. Pada remaja wanita median preferensi jumlah anak ideal adalah 2,6 dan pada remaja pria median preferensi jumlah anak ideal adalah 2,7 Jika dibandingkan SKRRI 2007 menunjukkan adanya sedikit peningkatan ratarata preferensi jumlah anak ideal pada remaja wanita dari 2,5 menjadi 2,6 . Untuk mencapai angka fertilitas 2,1 pada tahun 2025 perlu upaya besar bagi program KB untuk memberikan pemahaman tentang pentingnya $\mathrm{KB}$.

Health Belief Model (HBM) dikemukakan pertama kali oleh Resenstock tahun 1996. Dalam perilaku yang berkaitan dengan kesehatan sering kali menggunakan HBM sebagai kerangka utama. HBM merupakan teori yang digunakan untuk meranalkan perilaku peningkatan kesehatan. Ditinjau dari teori perilaku pencegahan HBM, keputusan seseorang untuk melakukan tindakan dipengaruhi oleh faktor sosio demografi (umur, jenis kelamin. pendidikan, pekerjaan), variabel sosiopsikologi, variabel struktural (pengetahuan dan sikap), ancaman yang dirasakan, dan petunjuk untuk berperilaku (informasi dari media, penyuluhan, informasi di sekolah).
Berdasarkan permasalahan tersebut, maka perlu diketahui tentang faktor yang berhubungan dengan keinginan menggunakan metode kontrasepsi pada remaja Provinsi Jawa Timur di masa mendatang Tahun 2015. Keterbatasan penelitian ini adalah tidak meneliti faktor sosial psikologi (kepribadian dan pengalaman) faktor struktural (pengetahuan dan sikap), ancaman yang dirasakan, petunjuk untuk berperilaku (niedia, orang lain, penyuluhan). Penelitian ini menganalisis hubungan antara karakteristik sosio demografi (usia, jenis kelamin, tempat tinggal dan tingkat pendidikan) dengan keinginan untuk menggunakan metode kontrasepsi pada remaja Provinsi Jawa Timur di masa mendatang tahun 2015.

\section{METODE PENELITIAN}

Penelitian ini menggunakan pendekatan analitik dengan cross sectional. Sumber data berasal dari data sekunder survei indikator RPJMN Tahun 2015. Besar sampel penelitian ini berjumlah 2.384 remaja 15-24 tahun yang belum menikah periode Januari hingga Desember 2015 di Provinsi Jawa Timur. Teknik pengambilan sampel menggunakan systematic random sampling.

Variabel penelitian ini diantaranya usia, jenis kelamin, tempat tinggal, tingkat pendidikan, dan keinginan menggunakan metode kontrasepsi pada remaja di masa mendatang. Penelitian ini menggunakan uji chi-square dengan tingkat kepercayaan sebesar $95 \%(\alpha=0,05)$ untuk melihat hubungan antar variabel.

\section{HASIL PENELITIAN}

Berdasarkan survei indikator kinerja RPIMN Provinsi Jawa Timur tahun 2015, jumlah remaja usia 15-24 tahun yang belum menikah sebesar 2,384 orang. Distribusi trekuensi berdasarkan keinginan menggunakan metode kontrasepsi di masa mendatang dapat dilihat pada gambar I menunjukkan bahwa remaja yang memiliki keinginan untuk menggunakan metode kontrasepsi di masa mendatang sebesar $56,2 \%$, remaja yang tidak ingin menggunakan metode kontrasepsi sebesar $10,7 \%$ sedangkan remaja yang belum tahu rencana masa depan apakah 


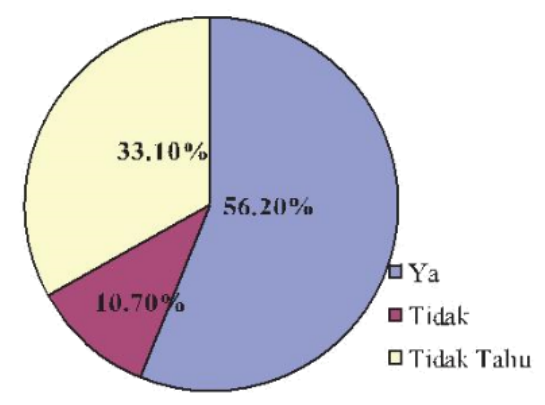

Gambar 1. Keinginan Menggunakan Metode Kontrasepsi pada Remaja di Provinsi Jawa

menggunakan metode kontrasepsi atau tidak sebesar $33,1 \%$.

\section{Keinginan Menggunakan Metode Kontrasepsi pada Remaja Berdasarkan Usia}

Keinginan menggunakan metode kontrasepsi pada remaja Provinsi Jawa Timur tahun 2015 berdasarkan usia, menjadi dua kategori yaitu usia 15-19 tahun dan usia 20-24 tahun. Pada tabel 2 menunjukkan bahwa pada kategori usia 15-19 tahun, terdapat 54,6\% yang menyatakan menginginkan menggunakan metode kontrasepsi di masa mendatang, 9,4\% menyatakan tidak ingin menggunakan metode kontrasepsi di masa mendatang, dan 36,0\% tidak tahu.

Pada kategori usia 20-24 tahun, terdapat $59,1 \%$ yang menyatakan menginginkan menggunakan metode kontrasepsi di masa mendatang, 12,9\% menyatakan tidak ingin menggunakan metode kontrasepsi di masa mendatang, dan $28,0 \%$ tidak tahu.

Remaja berusia $20-24$ tahun terdapat $59,1 \%$ responden cenderung lebih menginginkan untuk menggunakan metode kontrasepsi di masa mendatang, dibandingkan dengan remaja kelompok usia 15-19 tahun sebanyak 54,6\%. Namun, remaja berusia $20-24$ tahun $12,9 \%$ juga cenderung lebih tidak menginginkan untuk mengyunakan metode kontrasepsi di masa mendatang, dibandingkan dengan remaja kelompok usia 15-19 tahun sebanyak 9,4\%.

\section{Hubungan antara Usia dengan Keinginan Menggunakan Metode Kontrasepsi pada Remaja}

Pada tabel 1 diperoleh nilai p sebesar 0,000 berdasarkan hasil uji statistik Chi-Square. Hal ini dapat menunjukkan bahwa ada hubungan yang bermakna antara usia dengan keinginan menggunakan metode kontrasepsi pada remaja Provinsi Jawa Timur tahun 2015.

\section{Keinginan Menggunakan Metode Kontrasepsi pada Remaja Berdasarkan Jenis Kelamin}

Keinginan menggunakan metode kontrasepsi pada remaja Provinsi Jawa Timur tahun 2015 berdasarkan jenis kelamin dikategorikan menjadi dua kategori yaitu laki-laki dan perempuan. Pada

Tabel 1. Keinginan Menggunakan Metode Kontrasepsi Pada Remaja di Provinsi Jawa Timur Tahun 2015

\begin{tabular}{|c|c|c|c|c|c|c|c|c|c|c|}
\hline \multirow{2}{*}{\multicolumn{2}{|c|}{ Variabel }} & \multicolumn{2}{|c|}{$\mathbf{Y a}$} & \multicolumn{2}{|c|}{ Tidak } & \multicolumn{2}{|c|}{ Tidak Tahu } & \multicolumn{2}{|c|}{ Jumlah } & \multirow{2}{*}{$\mathbf{p}$} \\
\hline & & $\mathbf{n}$ & $\%$ & $\mathbf{n}$ & $\%$ & n & $\%$ & $\mathbf{n}$ & $\%$ & \\
\hline \multirow[t]{2}{*}{ Usia } & $15-19$ & 842 & 54,6 & 146 & 9,4 & 555 & 36,0 & 1.543 & 100,0 & \multirow{2}{*}{0,000} \\
\hline & $20-24$ & 497 & 59,1 & 109 & 12,9 & 235 & 28,0 & 841 & 100,0 & \\
\hline \multirow[t]{2}{*}{ Jenis Kelamin } & Laki-laki & 587 & 45,5 & 209 & 16,2 & 493 & 38,2 & 1.289 & 100,0 & \multirow{2}{*}{0,000} \\
\hline & Perempuan & 752 & 68,7 & 46 & 4,2 & 297 & 27,1 & 1.095 & 100,0 & \\
\hline \multirow[t]{2}{*}{ Tempat Tinggal } & Perkotaan & 657 & 56,3 & 101 & 8,6 & 410 & 36,9 & 1.168 & 100,0 & \multirow{2}{*}{0,003} \\
\hline & Pedesaan & 682 & 56,1 & 154 & 12,7 & 380 & 31,2 & 1.216 & 100,0 & \\
\hline Tingkat & Rendah & 747 & 51,4 & 170 & 11,7 & 537 & 36,9 & 1.454 & 100,0 & \multirow{2}{*}{0,000} \\
\hline Pendidikan & Tinggi & 586 & 64,0 & 81 & 8,8 & 249 & 27,2 & 916 & 100,0 & \\
\hline Jumlah & & 1.339 & 56,2 & 255 & 10,7 & 790 & 33,1 & 2.384 & 100,0 & \\
\hline
\end{tabular}

Sumber: Survei Indikator Kinerja RPJMN Tahun 2015 
tabel 1 menunjukkan bahwa pada kelompok jenis kelamin laki-laki, terdapat $45,5 \%$ menyatakan menginginkan menggunakan metode kontrasepsi di masa mendatang, 16,2\% menyatakan tidak ingin menggunakan metode kontrasepsi di masa mendatang, dan $38,2 \%$ tidak tahu. Pada kelompok jenis kelamin perempuan, terdapat $68,7 \%$ menyatakan menginginkan menggunakan metode kontrasepsi di masa mendatang, 4,2\% menyatakan tidak ingin menggunakan metode kontrasepsi di masa mendatang, dan 27,1\% tidak tahu. Remaja perempuan sebanyak $68,7 \%$ cenderung lebih menginginkan untuk menggunakan metode kontrasepsi di masa mendatang, dibandingkan dengan remaja lakilaki sebanyak 45,5\%. Remaja laki-laki sebanyak $16,2 \%$ cenderung lebih tidak menginginkan untuk menggunakan metode kontrasepsi di masa mendatang, dibandingkan dengan remaja perempuan $(4,2 \%)$.

\section{Hubungan antara Jenis Kelamin dengan Keinginan Menggunakan Metode Kontrasepsi pada Remaja}

Pada tabel 1 diperoleh nilai p sebesar 0,000 berdasarkan hasil uji statistik Chi-Square. Hal ini dapat menunjukkan bahwa ada hubungan yang bermakna antara jenis kelamin dengan keinginan menggunakan metode kontrasepsi pada remaja Provinsi Jawa Timur tahun 2015 dengan kuat hubungan sebesar 0,089 .

\section{Keinginan Menggunakan Metode Kontrasepsi pada Remaja Berdasarkan Tempat Tinggal}

Keinginan menggunakan metode kontrasepsi pada remaja berdasarkan tempat tinggal remaja dibagi menjadi dua kategori yakni perkotaan dan perkotaan. Pada tabel 1 menunjukkan bahwa pada kelompok remaja yang bertempat tinggal di perkotaan, terdapat $56,3 \%$ menyatakan menginginkan menggurakan metode kontrasepsi di masa mendatang, 8,6\% menyatakan tidak ingin menggunakan metode kontrasepsi di masa mendatang, dan 36,9\% tidak tahu. Pada kelompok remaja yang bertempat tinggal di pedesaan, terdapat $56,1 \%$ menyatakan menginginkan menggunakan metode kontrasepsi di masa mendatang, $12,7 \%$ menyatakan tidak ingin menggunakan metode kontrasepsi di masa mendatang, dan $31,2 \%$ tidak tahu.

Ada sedikit kecenderungan bahwa remaja bertempat tinggal di perkotaan sebanyak $56,3 \%$ cenderung lebih menginginkan untuk menggunakan metode kontrasepsi di masa mendatang, dibandingkan dengan remaja pendidikan rendah sebanyak $56,1 \%$. Remaja yang bertempat tinggal di pedesaan sebanyak $12,7 \%$ cenderung lebih tidak menginginkan untuk menggunakan metode kontrasepsi di masa mendatang, dibandingkan dengan remaja yang bertempat tinggal di perkotaan sebanyak $8,6 \%$.

\section{Hubungan antara Tempat Tinggal dengan Keinginan Menggunakan Metode Kontrasepsi pada Remaja}

Pada tabel 1 dapat diperoleh nilai $p$ sebesar 0,003 . Hal ini dapat diartikan bahwa ada hubungan yang bermakna antara tempat tinggal dengan keinginan menggunakan metode kontrasepsi pada remaja Provinsi Jawa Timur tahun 2015 dengan nilai kontingensi sebesar 0,07 .

\section{Keinginan Menggunakan Metode Kontrasepsi pada Remaja Berdasarkan Tingkat Pendidikan}

Keinginan menggunakan metode kontrasepsi pada remaja di masa mendatang berdasarkan tingkat pendidikan formal yang telah ditamatkan dibagi menjadi dua kategori yakni kategori pendidikan rendah dan pendidikan tinggi. Kategori pendidikan rendah terdiri dari remaja yang telah menempuh pendidikan formal mulai dari 0 tahun hingga 9 tahun sedangkan tingkat pendidikan tinggi terdiri dari remaja yang telah menempuh pendidikan formal lebih dari 9 tahuin.

Pada tabel 1 pada kelompok pendidikan rendah, terdapat $51,4 \%$ menyatakan menginginkan menggunakan metode kontrasepsi di masa mendatang, 11,7\% menyatakan tidak ingin menggunakan metode kontrasepsi di masa mendatang, dan 35,1\% tidak tahu. Pada kelompok pendidikan tinggi, terdapat $64 \%$ menyatakan menginginkan menggunakan Metode Kontrasepsi di masa mendatang, 8,8\% menyatakan tidak 
ingin menggunakan metode kontrasepsi di masa mendatang, dan $27,2 \%$ tidak tahu.

Remaja berpendidikan tinggi sebanyak $64 \%$ cenderung lebih menginginkan untuk menggunakan metode kontrasepsi di masa mendatang, dibandingkan dengan remaja pendidikan rendah sebanyak $51,4 \%$. Remaja berpendidikan rendah sebanyak $11,7 \%$ cenderung lebih tidak menginginkan untuk menggunakan metode kontrasepsi di masa mendatang, dibandingkan dengan remaja pendidikan tinggi sebanyak $8,8 \%$.

\section{Hubungan antara Tingkat Pendidikan dengan Keinginan Menggunakan Metode Kontrasepsi pada Remaja}

Pada tabel I diperoleh nilai p sebesar 0,000 . Hal ini dapat diartikan bahwa ada hubungan yang signifikan antara tingkat pendidikan dengan keinginan mengsuuakan metode kontrasepsi pada remaja Provinsi Jawa Timur tahun 2015.

\section{PEMBAHASAN}

Hubungan antara Usia dengan Keinginan Menggunakan Metode Kontrasepsi pada Remaja

Terdapat hubungan yang bermakna antara usia dengan keinginan menggunakan metode kontrasepsi pada remaja Provinsi Jawa Timur tahun 2015 dengan kuat hubungan sebesar 0,248 . Remaja berusia 20-24 tahun sebanyak $59,1 \%$ cenderung lebih menginginkan untuk menggunakan metode kontrasepsi di masa mendatang, dibandingkan dengan remaja kelompok usia 15-19 tahun sebanyak 54,6\%. Hasil penelitian ini searah dengan hasil analisis Anggraeni (2009) pada kelompok remaja Indonesia yanı menyatakan bahwa terdapat hubungan antara usia dengan keinginan menggunakan KB.

Remaja yang lebih tua berniat untuk menggunakan alat kontrasepsi jika remaja tersebut menikah atau bersedia untuk menggunakan kontrasepsi untuk menunda atau menghindari kehamilan dibandingkan pada kelompok remaja yang lebih muda. Hasil ini juga sesuai dengan penelitian Adogu et al.,(2014) dimana remaja dengan usia yang lebih tua menjadi faktor prediktor dalam penggunaan alat kontrasepsi (kondom). Remaja yang lebih tua memiliki perencanaan yang lebih matang terkait kehidupan di masa depan karena semakin bertambah usia akan semakin berkembang pula daya tangkap dan pola pikirnya, sehingga pengetahuan yang diperolehnya semakin baik.

Menurut Ayunda (2012) remaja pada usia yang masil muda cenderung lebih tertutup dalam membahas hal-hal yang berkaitan dengan seksual.

Hubungan antara Jenis Kelamin dengan Keinginan Menggunakan Metode Kontrasepsi pada Remaja

Terdapat hubungan yang bermakna antara jenis kelamin dengan keinginan menggunakan metode kontrasepsi pada remaja Provinsi Jawa Timur tahun 2015 dengan kuat hubungan sebesar 0,089 . Remaja perempuan sebanyak $68,7 \%$ cenderung lebih menginginkan untuk mengyunakan metode kontrasepsi di masa mendatang, dibandingkan dengan remaja lakilaki sebanyak $45,5 \%$. Hasil penelitian ini sesuai dengan hasil analisis Anggraeni (2009) pada kelompok remaja di Indonesia, dimana keinginan menggunakan metode kontrasepsi pada kelompok remaja perempuan di masa mendatang 9,1 kali lebih besar dibandingkan pada kelompok remaja laki-laki.

Program KB belum mendapatkan dukungan penuh dari masyarakat terutama pada partisipasi pria/suami. Penggunaan metode kontrasepsi oleh pria masih sangat rendah. Peserta KB di Indonesia masih didominasi oleh kaum wanita. Berbeda dengan di Amerika jumlah peserta KB dari kaum laki-laki sudah menyaingi peserta KB perempuan (BKKBN, 2012).

Keadaan tersebut mencerminkan bahwa di negara maju sudah terdapat persamaan gender antara laki-laki dan perempuan dimana KB dan kesehatan reproduksi bukan hanya tanggung jawab perempuan saja. Sama halnya pada kelompok remaja, remaja laki-laki lebil cenderung tidak ingin menggunakan $\mathrm{KB}$ apabila sudah menikah dan menganggap bahwa KB merupakan urusan perempuan. Keterlibatan laki-laki dalam pendidikan KB dan layanan juga harus mempertimbangkan keseimbangan 
gender sehingga tidak menghilangkan kontrol perempuan atas keputusan kesehatan reproduksi. Pentingnya peran serta laki-laki dalam program KB juga didukung oleh Gara dan Singh (2014) menyatakan bahwa program kesejahteraan keluarga harus mendidik dan memungkinkan untuk berbagi pekerjaan yang seimbang dalam hal $\mathrm{KB}$, rumah tangga dan tanggung jawab anak.

Hasil penelitian ini searah dengan hasil analisis SDKI tahum 2007 pada kelompok remaja, dimana keinginan menggunakan metode kontrasepsi pada kelompok remaja perempuan lebih tinggi dibandingkan pada kelompok remaja laki-laki. Remaja perempuan lebih mungkin menggunakan metode kontrasepsi di masa mendatang:

\section{Hubungan antara Tempat Tinggal dengan Keinginan Menggunakan Metode Kontrasepsi pada Remaja}

Tempat tinggal remaja memiliki hubungan yang bermakna dengan keinginan menggunakan metode kontrasepsi pada remaja Provinsi Jawa Timur tahun 2015 dengan kuat hubungan sebesar 0,07. Ada sedikit kecenderungan bahwa remaja bertempat tinggal di perkotaan sebanyak 56,3\% cenderung lebih menginginkan untuk menggunakan metode kontrasepsi di masa mendatanı, dibandingkan dengan remaja pendidikan rendah sebanyak $56,1 \%$.

Hasil tersebut sejalan dengan hasil analisis lanjut SDKI yang dilakukan oleh BKKBN, didapatkan bahwa persentase di perkotaan yang ingin menggunakan metode kontrasepsi di masa mendatang di perkotaan 545 sedangkan di pedesaan $46 \%(\mathrm{p}=0,000)(\mathrm{BKKBN}, 2009)$.

$\mathrm{Hal}$ ini dapat dikarenakan kepercayaan atau stigma masyarakat di daerah pedesaan terhadap isu kesehatan reproduksi masih sangat sensitif, ketersediaan tenaga pelayanan kesehatan terbatas serta akses terhadap pelayanan kesehatan yang belum merata di seluruh wilayah Indonesia (Kemenkes, 2013).

\section{Hubungan antara Tingkat Pendidikan dengan Keinginan Menggunakan Metode Kontrasepsi pada Remaja}

Tingkat pendidikan remaja mmeliki hubungan yang signifikan dengan keinginan menggunakan metode kontrasepsi pada remaja Provinsi Jawa Timur tahun 2015 dengan kuat hubungan sebesar 0,123 .

Remaja berpendidikan tinggi $(64 \%)$ cenderung lebih menginginkan untuk menggunakan metode kontrasepsi di masa mendatang, dibandingkan dengan remaja pendidikan rendah $(51,4 \%)$.

Remaja berpendidikan rendah $(11,7 \%)$ cenderung lebih tidak menginginkan untuk menggunakan metode kontrasepsi di masa mendatang, dibandingkan dengan remaja pendidikan tinggi $(8,8 \%)$

Tingkatan pendidikan berpengaruh terhadap kemudahan dalam menerima berbagai informasi dan memberi respons. Orang yang berpendidikan tinggi akan mudah dalam menerima informasi dan memberikan respons terhadap informasi yang datang serta berfikir manfaat yang mungkin akan mereka peroleh dari gagasan tersebut. (Notoatmojo, 2010). Searah dengan hasil analisis yang dilakukan oleh Gupta et al. (2003) yang menyatakan bahwa tingkat pendidikan memiliki hubungan yang signifikan dengan niat penggunaan kontrasepsi di masa depan.

Penelaahan terhadap beberapa penelitian sebelumnya menyimpulkan bahwa pendidikan seksualitas yang diberikan pada saat menempuh pendidikan formal tidak menyebabkan terjadinya hubungan seks lebih dini. Kegiatan tersebut juga tidak mengakibatkan bertambahnya kegiatan seksual remaja atau kaum muda. Pemberian edukasi mengenai seks aman dan kontrasepsi dalam rangka penundaan kegiatan seks lebih efektif dibandingkan dengan program yang hanya mendukung untuk tidak berhubungan seks di luar pernikahan (abstinence) (UNFPA, 2010).

\section{SIMPULAN DAN SARAN}

\section{Simpulan}

Berdasarkan hasil penelitian dan pembahasan sebelumnya, remaja yanz memiliki keinginan untuk menggunakan metode kontrasepsi di masa mendatang sebesar $56,2 \%$, remaja yang tidak ingin menggunakan metode kontrasepsi sebesar $10,7 \%$, dan $33,1 \%$ menyatakan tidak tahu. Ada hubungan yang bermakna antara usia, jenis kelamin, tempat tinggal dan tingkat pendidikan dengan keinginan 
menggunakan metode kontrasepsi di masa mendatang pada remaja Provinsi Jawa Timur tahun 2015.

\section{Saran}

Berdasarkan kesimpulan tersebut, BKKBN berkerjasama dengan duta Genre, dan tenaga pendidik untuk lebih meningkatkan sosialisi tentang Keluarga Berencana (KB) ayar dapat memberikan motivasi kepada kaum muda dalam merencanakan keluarga di masa mendatang. Selain itu perlunya peningkatan pengetahuan kesehatan reproduksi dan KB bagi remaja berbasis sekolah maupun berbasis masyarakat melalui penyuluhan dan media. Media massa (televisi, radio, majalah) dan media luar ruang (pamflet, spanduk, dll).

\section{DAFTAR PUSTAKA}

Adogu P, Udigwe I, Udigwe G., Nwabueze A., Onwasigwe C. 2014. Pattern, Types and Predictors of Contraception among Female In-School and Out-of-School Adolescents in Onitsha, Anambra State, Nigeria Advances in Sexual Medicine, 4 : pp. 33-41. Tersedia di http://dx.doi.org/10.4236/asm.2014.43007> [diakses tanggal 2 Agustus 2017].

Amazigo, U., Nancy, S., Joan, K., Daniel, S. 1997. Sexual Activity and Contraceptive Knowledge and Use Among In-School Adolescent in Nigeria. International Family Planning Perspective: $23: 28-33$.

Anggraeni, M. 2009. Gambaran Remaja dalam Keikutsertaan Ber-KB di Masa yang Akan Datang. Jurnal Ilmiah Keluarga Berencana dan Kesehatan Reproduksi. BKKBN 3 (1): 76-95.
Appiah-Agyekum, N.N., \& Kayi, E.A. 2013. Students' Perceptions of Contraceptives in University of Ghana. Journal of Family \& Reproductive Health, (1), 39-44.

Badan Pusat Statistik. 2013. Proyeksi Penduduk Indonesia 2010 - 2035. Jakarta: Badan Pusat Statistik Nasional.

Garg, S., and Singh, R. 2014. Need for Integration of Gender Equity in Family Planning Service. Journal of Medical Research, 140 (Supplement 1), pp. \$ $147-\$ 151$

Gupta, N., Katende, C. and Bessinger, R. 2003. Associations of Mass Media Exposure with Family Planning Attitudes and Practices in Uganda. Studies Fumily Planning, 34: 19-31. Tersedia di: <doi: $10.1111 / 1.1728-$ 4465.2003.00019. $x>$ [diakses tanggal 2 Agustus 2017 ].

Kementerian Kesehatan RI. 2013. Rencana $4 k s i$ Nasional Pelayanan Keluarga Berencana tahun 2014-20/5. Diunduh dari http:/www. gizikia.depkes.go.id/wpcontent/uploads/ downloads/2014/01/RAN-PELAYANAN-KB. pdf diakses pada 3 Agustus 2017.

Mfono, Z. 1998. Teenaye Contraceptive Needs in Urban South Africa a case study. International Family Planning Perspective. 24:180-183. Tersedia di \&doi: $10.2307 / 2991977>$ diakses pada 5 September 2017.

Musafaah 2007. Pengetahuan dan Sikap Pemakaian Kontrasepsì pada Remaja Putri Gaul di Parkir Timur Senayan, Jakarta. Junal Kesehatan Masyarakat, Vol 2 No. 2 pp: $91-96$.

Notoatmodjo. 2014. Imu Perilaku Kesehatan. Jakarta: Rineka Cipta.

Suryani, Y. 2015. Preferensi Remaja dalam Keluarga Berencana di Masa Depan (Studi pada Remaja di Kecamatan Kaliwates Kabupaten Jember). Jember: Universitas Jember. 